University at Buffalo School of Law

Digital Commons @ University at Buffalo School of Law

\title{
Justice Under Siege: The Rule of Law and Judicial Subservience in Kenya
}

Makau wa Mutua

University at Buffalo School of Law

Follow this and additional works at: https://digitalcommons.law.buffalo.edu/journal_articles

Part of the Judges Commons, and the Rule of Law Commons

\section{Recommended Citation}

Makau w. Mutua, Justice Under Siege: The Rule of Law and Judicial Subservience in Kenya, 23 Hum. Rts. Q. 96 (2001).

Available at: https://digitalcommons.law.buffalo.edu/journal_articles/569

Copyright (c) 2001 The Johns Hopkins University Press. This article was first published in Human Rights Quarterly 23.1 (2001), 96-118. Reprinted with permission by Johns Hopkins University Press.

\section{IN COPYRIGHT}

This Article is brought to you for free and open access by the Faculty Scholarship at Digital Commons @ University at Buffalo School of Law. It has been accepted for inclusion in Journal Articles by an authorized administrator of Digital Commons @ University at Buffalo School of Law. For more information, please contact lawscholar@buffalo.edu. 


\title{
Justice Under Siege: The Rule of Law and Judicial Subservience in Kenya
}

\author{
Makau Mutua*
}

\section{INTRODUCTION}

Constitutionalism and the rule of law are the central features of any political democracy that respects human rights. An independent judiciary, the essential guardian of the rule of law, is the linchpin of the scheme of checks and balances through which the separation of powers is assured.' Otherwise, there is no other guarantee that the executive-the "government" will respect the rule of law and act within established legal norms,

* Professor Makau Mutua is Professor of Law and Director of the Human Rights Center at the State University of New York, Buffalo School of Law where he teaches international human rights, international business transactions, and international law. Professor Mutua has been a Visiting Professor at Harvard Law School, the University of lowa College of Law, and the University of Puerto Rico School of Law. He was educated at the University of Nairobi, the University of Dar-es-Salaam, and at Harvard Law School, where he obtained a Doctor of Juridical Science in 1987.

Professor Mutua was Co-Chair of the 2000 Annual Meeting of the American Society of International Law.

Professor Mutua has written numerous scholarly articles exploring topical subjects in international law, human rights, and religion. These include "The Ideology of Human Rights," "Hope and Despair for a New South Africa: the Limits of Rights Discourse," "The Banjul Charter and the African Cultural Fingerprint: an Evaluation of the Language of Duties," and "Why Redraw the Map of Africa: a Moral and Legal Inquiry." He has written human rights reports for the United Nations and leading NGOs. He has authored dozens of articles for popular publications such as the New York Times and the Washington Post.

Previously, Professor Mutua was the Associate Director at the Harvard Law School Human Rights Program. He was also the Director of the Africa Project at the Lawyers Committee for Human Rights. He serves as Chairman of the Kenya Human Rights Commission and sits on the boards of several international organizations and academic journals.

He has conducted numerous human rights, diplomatic, and rule of law missions to countries in Africa, Latin America, and Europe. He has spoken at public fora in many parts of the world, including Japan, Brazil, France, and Ethiopia.

1. See Henry J. Steiner \& Philip Alston, International. Human Rights in Context: Law, Politics, MORALS 711-12 (1996). 
processes, and institutions. The constitution is thus not merely hortatory but the fundamental and supreme law of the land, the real and living document that guides, defines, and permits all actions by the state. No individual or official of the state is above the law or can act in defiance of constitutional prescriptions. This is what separates democratic states from undemocratic ones. It is the difference between tyranny and freedom.

Since its creation by the British in 1895, the Kenyan state has undergone two significant transformations, both marked by illiberalism and massive human rights violations. Little need be said of the colonial state that was specifically organized for the purposes of political repression to facilitate economic exploitation. In 1963, Kenya formally became an independent, sovereign state, ending decades of direct British colonial rule. ${ }^{2}$ Kenya's postindependence history, however, has been marked by sharp contradictions between the state and civil society in spite of its image, cultivated in the West during the Cold War, that the east African state was the beacon of hope for Africa. Not even the reintroduction of multipartyism in 1991 nor the two contested presidential and parliamentary elections in 1992 and 1997 have brought relief from state-directed human rights violations, an abomination that has become the trademark of the Nairobi government.

Kenya's 1963 independence Constitution provided for a multiparty democracy, a freely elected bicameral Parliament, and guaranteed judicial independence. ${ }^{3}$ In spite of the liberal Constitution, the post-colonial state was autocratic at its inception because it wholly inherited the laws, culture, and practices of the colonial state. In 1964, Daniel Toroitich Arap Moi, President of Kenya since 1978, voluntarily dissolved the opposition party, the Kenya African Democratic Union (KADU). He then joined the ruling Kenya African National Union (KANU), headed by the nation's first African head of state, the late Mzee Jomo Kenyatta. The "merger made Kenya a de facto one party state and paved the way for a despotic executive." ${ }^{\prime 4}$

In the absence of any legalized and official opposition and despite the Constitution's allowance of parliamentary democracy, President Kenyatta quickly created a highly centralized, authoritarian republic, reminiscent of the colonial state. Although Oginga Odinga, then Vice President, broke ranks to form the opposition Kenya Peoples' Union (KPU), President Kenyatta outlawed it in 1969 and detained all its principal leaders. ${ }^{5}$ Upon

\footnotetext{
2. See Africa Watch, Kenya: Taking Liberties 5 (1991).

3. See H. W. O. Okoth-Ogendo, Law and Government in Kenya: An Official Handobok 27-35 (Republic of Kenya: Ministry of Information and Broadcasting, 1988).

4. See Makau wa Mutua, Human Rights and State Despotism in Kenya: Institutional Problems, 41 Afr. Today 50 (1994); See also Jennifer Widner, The Rise of a Party State in Kenya: From Harambee! to Nrayo! (1992).
}

5. See International Commission of Jurists, Democratisation and the Rule of law in Kenya 11 (1997) [hereinafter Democratisation]. 
President Kenyatta's death, Vice President Moi succeeded to the presidency in 1978. Insecure at first, President Moi quickly took a number of important measures to consolidate personal rule. The net effect of these measures was to heighten repression and dramatically curtail all freedoms. Mismanagement, official corruption, and graft skyrocketed. The national economy has since spiraled into a precipitous decline. ${ }^{6}$

In June 1982, after popular calls for an open political system, President Moi pushed a constitutional amendment through the single party Parliament making Kenya a de jure one-party state. ${ }^{7}$ Several months later, an aborted coup by a section of the Kenyan Air Force spurred President Moi to crush all dissent and concentrate all power into his hands. From then on, President Moi worked to perfect the repressive state crafted by President Kenyatta. Through the government and KANU, he exercised extensive and deep control over civic groups, trade unions, the press, the Parliament, and most critically, the judiciary. Political murder, detention without trial, arbitrary arrests and detentions, false and politically motivated charges of opponents, both real and imagined, became the business of the state. State and KANU officials committed crimes with impunity. Laws and constitutional amendments that abrogated due process protections and the independence of the judiciary were passed without parliamentary debate or resistance. ${ }^{8}$

Even after the authorization of open political competition in 1991, President Moi and KANU have continued to resist the installation of democracy. The government has used all its resources to frustrate a genuine transition to democracy. Since 1992, the state periodically has engineered and orchestrated inter-ethnic violence, particularly against communities that support opposition political parties. The police and security forces constantly invoke colonial era legislation to restrict the activities of the press and civic and human rights groups. The judiciary, which lacks independence and is viewed by Kenyans as subservient to the executive, continues to be a captive instrument of repression. ${ }^{9}$

This article frankly and critically discusses and analyzes the state of the Kenyan judiciary and the problems that beset it in acting as the custodian of the rule of law. The article argues that the judiciary has been subservient to

6. See Human Rights Watch, World Report 2000: Events of 1999, 48-50 (2000).

7. See Const. of KenYA, $\$ 2$ (a) amend., act No. 7 (1982). In 1982, President Moi forced a constitutional amendment, making Kenya officially a one-party state. It provided that: "There shall be in Kenya only one political party, the African National Union."

8. See James Gathil, The Dream of Judicial Security of Tenure and the Reality of Executive Involvement in Kenya's Judicial Process 14 (1994) [a Kenya Human Rights Commission publication].

9. See Drew Days III et al., Justice Enjoined: The State of the Judiciary in Kenva 4 (1992) la publication of the Robert F. Kennedy Memorial Center for Human Rights]; see also Human Rights Watch supra note 6, at 48. 
the executive. The judiciary has shown no ability or inclination to uphold the rule of law against the express or perceived whims and interests of the executive and individual senior government officials, their business associates, and cronies. The government has acted swiftly and expeditiously to discipline or dismiss individual judges and magistrates who occasionally have failed to carry out its wishes. The judiciary has ruled consistently in favor of the KANU elite and its supporters in cases involving their corrupt practices and political interests. In fact, the judiciary has been only too eager to protect the political monopoly of the KANU. State officials and business associates of leading public servants have sought the protection of the legal system and the judiciary for their illegal actions as official corruption has become the norm. An aggrieved party cannot expect the rule of law to be upheld by a Kenyan court if the offender is a public official or is connected to the KANU elite. An umbrella of protection covers the illegal actions of the KANU ruling elite and its surrogates. This article concludes that nothing short of radical surgery of the norms, institutions, and personnel that comprise the legal and political structures of the Kenyan state can restore the judiciary's role as the guarantor of legality and the guardian of human rights.

\section{LAW AND POLITICS}

Law and politics have always been intertwined since the birth of the Kenyan republic in 1964. Although the Kenyan Constitution guarantees fundamental rights on its face, the government has substantially eroded and weakened many of the safeguards since independence. The Bill of Rights ${ }^{10}$ gives individuals basic rights but then restricts them with qualifying limitations, otherwise known as clawback clauses." Derogations from the Bill of Rights are also constitutionally permitted during an emergency. ${ }^{12}$ The first major blow to the rule of law came in 1966 when the young republic passed the Preservation of Public Security Act (PPSA), ${ }^{13}$ in essence reenacting colonial

10. See Const. of KenYa ch. V, \$§ 70-83.

11. For instance, the Constitution of Kenya protects individuals against arbitrary search and entry but then qualifies such protection, in part, in the following language:

Nothing contained in or done under the authority of any law shall be held to be inconsistent with or in contravention with this section to the extent that the law in question makes provision (a) that is reasonably required in the interests of defense, public safety, public order, public morality, public health, town and country planning, the development and utilization of mineral resources, or the development and utilization of any other property in such a manner as to promote the public benefit.

Const. Of Kenya ch. 5, §§ $76(1-2)$.

12. See Const. of KenYa ch. $V, \S 83$.

13. See CAP. 57, Laws of Kenya. 
detention laws. Under the PPSA, the government detained scores of its outspoken critics, and in the process stifled calls for democratic change and an open society. Although on its face constitutional-and even formally a democracy since 1992-the Kenyan state is in reality highly repressive and authoritarian, trapped in the culture of the one-party state.

In a telling admission of lawlessness, Attorney General Amos Wako stated in 1991 that "a characteristic of the rule of law is that no man, save for the president, is above the law." ${ }^{14}$ As noted by the respected Genevabased International Commission of Jurists, the "Executive is still an overacting and predatory institution shadowing and preying upon the other two constitutionally coequal branches of government-the Legislature and the Judiciary." 15 Indeed, the last decade of multipartyism has witnessed the increased fragmentation of Kenya and the escalation of the divide and rule tactics of the Moi government. State despotism has sapped the energy of virtually all sectors of society-the Parliament, the political opposition, trade unions, non-governmental organizations (NGOs), the press, and opposition political parties-through intimidation, official corruption, arbitrary arrests, and the persecution of political opponents. Unfortunately, the judiciary has been only too eager to be used by the government as an instrument of repression. As a result, the country now dances on the precipice, in all respects ready to join its neighbors as a dysfunctional or failed state.

\section{THE COURTS AND THE LEGAL SYSTEM}

The judiciary is supposed to be the guarantor of any legal system. The Kenyan legal system is composed of the judiciary, law enforcement agencies, the Office of the Attorney General, and the private bar organized under the auspices of the Law Society of Kenya (LSK). The Constitution of Kenya creates the High Court and the Court of Appeal, the highest courts in the land. ${ }^{16}$ The High Court, however, exercises original jurisdiction on all matters and is therefore the most important court in the country. In particular, the High Court has the final authority over matters of constitutional interpretation. It also exercises appellate jurisdiction over all decisions of the Magistrates Courts, where the bulk of litigation takes place in Kenya. ${ }^{17}$ The Court of Appeal may review decisions of the High Court where

14. The Rule of Law Will Prevail, Wefkly Rev., 12 July 1991, at 26 [reprint of the Attorney General's first speech to Parliament].

15. Democratisation, supra note 5 , at 19 .

16. See Const. Of KenYA ch. IV, pt. 1, $\S \S 60(1), 64(1)$.

17. See id. 
the latter has original jurisdiction. ${ }^{18}$ Except for High Court rulings on constitutional questions, the Court of Appeal may also review High Court opinions on matters of law. The judiciary is supposed to be separate and independent from the executive. Abstractly, this structure appears rational and sensible. The devil, however, is in the specifics and the history of the manipulation by the executive of the judiciary and the legal system to concentrate power in the presidency and the ruling party.

The passage of the detention law in 1966 started a broad but steady attack on the rule of law and integrity of the judiciary and the legal system. When the government converted Kenya from a de facto one party system to a de jure one party state in 1982, even the private bar was so steeped in the culture of subservience that it did not openly challenge this fundamental shift and rejection of democracy. However, relations between the state and the private bar started to deteriorate when in 1986, in another dramatic departure from the rule of the law, President Moi arrogated to himself through law the power to dismiss both the Attorney General and the Auditor General at will. ${ }^{19}$ The removal of security of tenure, and therefore independence, for these two key government officers signaled a disregard of the importance of tenure for officials that uphold the rule of law and make sure that the government acted within legal bounds. It further opened the door to impunity and made possible imminent attacks on judicial independence.

As is well known, during the colonial era, judges served at the pleasure of the Crown. ${ }^{20}$ However, the independence Constitution seemed to change the nature of the relationship between the executive and the judiciary. It stated that "[a] Judge of the High Court may be removed from office only for inability to perform the functions of his office (whether arising from infirmity of body or mind or from any other cause) or for misbehavior, and shall not be so removed except in accordance with this section." 21

In fact, the independence Constitution provided for a complex process of the removal of judges, deliberately insulating them from executive power. Removal of a judge was only possible after a presidentially appointed tribunal had considered the matter and made recommendations to the president. ${ }^{22}$ However, the force of habit and the culture of subservience to officialdom was too difficult to overcome, despite the protections provided for in the independence Constitution. The regimes of President Kenyatta and

18. See Const. Of KenYa ch. IV, pt. I, § 64(1).

19. See Drew Dars III et al., Justice Enjoined: The State of the Judiciary in Kenya 4 (1992) [a publication of the Robert F. Kennedy Memorial Center for Human Rights].

20. See Yash Ghal \& I.W.P.B. Mcauslan, Public Law and Political Change in Kenra: 1865-1970, 173 (1970).

21. Const. of KenYa ch. IV, pt. I, § 62(3).

22. See Const. of KenYa ch. IV, pt. I, $\$ 62(4-7)$. 
President Moi, his successor, treated the courts just like any other agency within the executive. Finally in 1988, President Moi prevailed over the rubber stamp Parliament to pass a constitutional amendment with farreaching implications for judicial independence and respect for human rights in Kenya. In a stunning act of docility, the KANU Parliament removed the security of tenure for judges. It also extended from twenty-four hours to fourteen days the period during which suspects in capital cases could be held without charge. ${ }^{23}$ However, in 1990 under intense pressure both domestically and internationally, President Moi buckled and instructed the Parliament to restore judicial security of tenure. ${ }^{24}$ Although the constitutional amendment technically restored almost all of the judicial tenure provisions of the independence Constitution, the damage had already been done. ${ }^{25}$ Once tenure is abolished there is no guarantee that it will not happen again. The chill introduced by such blatant disregard for a basic constitutional principle by the executive underlined the subordinate status of the courts in Kenya.

Legal systems cannot function effectively to guarantee basic rights if the private bar is not free of state coercion. Until 1986 when the Moi government carried out widespread arrests and committed egregious human rights violations against outspoken critics ostensibly in pursuit of Mwakenya, a small underground movement, the private bar had been solidly allied with the KANU government. ${ }^{26}$ Only two lawyers had previously been targets of the state. Willy Mutunga, a law lecturer, was detained in 1982 for allegedly teaching "subversion." John Khaminwa met a similar fate in 1984 for representing a political detainee. ${ }^{27}$ However, such confrontations between private attorneys and the state were the exception, as the profession had generally chosen to support the state. That peaceful coexistence ended in 1986 with the arrest and detention of two lawyers, Wanyiri Kihoro and Mirugi Kariuki, for alleged connections with Mwakenya. ${ }^{28}$

In February 1987, the government detained Gibson Kamau Kuria, a law lecturer and a prominent Nairobi lawyer, for filing a habeas corpus application on behalf of Mirugi Kariuki. ${ }^{29}$ The arrest of the three lawyers, and particularly that of Kuria, a widely respected moderate, drew intense

\footnotetext{
23. See Const. of Kenra amend. act no. 4 (1988).

24. See Const. of Kenya amend. act no. 1 (1990).

25. See DaYs ET. Al., supra note 19 , at 21.

26. See David Gilles \& Makau Mutua, a long Road to Uhuru: Human Rights and Political PARTICIPATION IN KenYa 22 (1993) [a publication of the Montreal-based International Centre for Human Rights and Democratic Developmentl.

27. See id.

28. See Africa Watch, supra note 2, at 128.

29. See Dars Et Al., supra note 19 , at $42-43$.
} 
domestic and international scrutiny. The LSK, seeing the attack as destructive to the profession, joined the battle to press for the release of the three lawyers. It also became more outspoken of human rights abuses by the government. The government retaliated by promulgating regulations to require that lawyers obtain annual practice licenses. ${ }^{30}$ The government then tried but failed to affiliate the LSK to KANU. It also unsuccessfully tried to manipulate the LSK's election in favor of pro-government candidates. Finally, Paul Muite, a leader of the pro-democracy movement, was elected to the helm of the LSK in 1991, beating state-directed efforts to stop him. At his acceptance speech, Muite, the widely respected opposition politician, pointed the finger directly at the state. The government, he categorically said:

must continue to be told by us lawyers that the greatest threat to public security is not us lawyers, when we speak out ... [T] The greatest danger to public security is the Kenya government itself. It can remove that danger by adhering to the constitution, both in theory and practice. By faithfully subscribing to the Rule of Law, democracy and respect for fundamental human rights, "threat to public security" will become a thing of the past. ${ }^{31}$

Since then, successive chairs of the LSK_particularly Willy Mutunga and Gibson Kamau Kuria-have turned it into a leading voice for democratic reform, the rule of law, and the independence and integrity of the judiciary and the legal system. ${ }^{32}$ However, as Human Rights Watch, the respected New York based human rights group noted in its 2000 annual report, the government has resisted these calls, and instead further heightened its attacks on the legal system.

The link between corruption and eroded respect for human rights was most evident in the judiciary, the provincial administrations, and the police. The government had always used the judiciary for political ends. In September [1999], the sudden death of Chief Justice Zachaeus Chesoni, resulted in the appointment of the public prosecutor, Bernard Chunga, as chief justice. The appointment of Chunga, known for his zealous prosecution of government critics, caused an uproar in the legal community and appeared to signal a serious step backwards for judicial independence. ${ }^{33}$

30. See DaYS et AL., supra note 19, at 49. (Lawyers would have been required to obtain licenses under the Trade Licensing Act) CAP. 497, Laws of Kenya.

31. See Dars et Al., supra note 19 , at 51 .

32. See, e.g., Parliament Condemned for Downsizing Corruption List, Africa News, 20 July 2000, available on Lexis, News Library; Kenya Stalls on Political Reform But Aid Pours In, Dally Telegraph, 10 Mar. 1995, at 17.

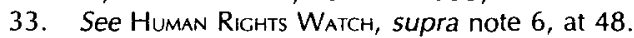




\section{JUDICIAL APPOINTMENTS}

There is a two-tiered system for the appointment of judges and magistrates in Kenya. Neither mechanism seems to secure judicial independence and at least both raise serious questions about the government commitment to the rule of law. In both instances, the Judicial Service Commission (JSC) plays an important role. The JSC is composed of the Chief Justice, the Attorney General, two judges appointed by the president, and the Chairman of the Public Service Commission. ${ }^{34}$ In any case, all JSC members are presidential appointees, either directly or indirectly, because he appoints the Attorney General, the Chief Justice, and the Chairman of the Public Service Commission. Thus the president personally composes, without any constitutionally required oversight or mandatory input from any other source, the most important judicial commission in the country.

Presidential control over the judiciary extends to the appointment of the judges of the High Court. As provided for in the Constitution, the "puisne judges," judges of the High Court, excepting the Chief Justice shall be appointed by the President acting in accordance with the advice of the Judicial Service Commission. ${ }^{35}$ However, even if the JSC was to think independently, its advice does not legally bind the president. The reality is that the Office of the President together with the Chief Justice-who is appointed for his affinity to President Moi and KANU—select the judges. The selection of judges to the High Court therefore does not involve the solicitation of the views of any outside or professional body such as the LSK. Even a body appointed by the late Chief Justice Chesoni, a close ally of President Moi, recently recommended reform of the JSC to democratize it and disentangle it from domination by the presidency. It recommended that:

The Judicial Service Commission should be completely overhauled to provide for the representation of the Law Society of Kenya and the Kenya Magistrates and Judges Association. The representatives of the Court of Appeal and the High Court on the Judicial Service Commission should be elected by the judges of those courts and not just selected as is the practice at the moment and should not serve for more than one term of four (4) years at a time. The Commission should also have its own secretariat separate from the Registrar of the High Court. ${ }^{36}$

The Kwach Report, ${ }^{37}$ named for the chair of the committee that produced it, addresses a wide range of problems that have crippled the

34. See Const. OF KenYa ch. IV, pt. III, $\$ 68(1)$.

35. See Const. of KenYa ch. IV, pt. I, § 61(2).

36. Republic of Kenya, Report of the Committee on the Administration of Justice: Summary of Recommendations 24 (1998) [hereinafter Kwach Report].

37. See id. 
judiciary. These include terms and conditions of service, questions of corruption and discipline within the judiciary, and structural, logistical, and organizational problems. Although some steps are apparently being taken to look into some of the minor recommendations by the report, it is doubtful that the nature of the JSC, which would require a constitutional amendment to reform, will be addressed any time soon, if ever. ${ }^{38}$

The domination of the judiciary by the executive cascades downward to the Magistrates Court, where most cases are heard in Kenya. The Judicial Service Commission, the presidential instrument, exercises complete control over the appointment of magistrates. As pointed out by James Gathii, "neither the Kenyan Constitution nor any Kenyan law guarantees judicial officers manning subordinate [magistrates] courts any form of security of tenure." ${ }^{\prime 39}$ Kenya's bifurcated judiciary permits the state to treat magistrates courts as an extension of its police and security apparatus, as most of the magistrates are appointed through patronage, and are expected to carry out the wishes of the executive if they intend to keep their jobs. ${ }^{40}$ Under the circumstances, it is impossible to see how any magistrate, no matter how courageous, can assert independence in matters in which the state has a direct interest.

\section{REMOVAL AND SECURITY OF TENURE}

Judges, whether appointed or elected, shall have guaranteed tenure until a mandatory retirement age or the expiry of their term of office. ${ }^{41}$ The government views the security of tenure for judges as a great inconvenience. It removed such formal, constitutional security in 1988 and only restored it in 1990 after the suspension of military assistance by the United States. ${ }^{42}$ Under the 1990 constitutional amendment restoring judicial tenure and security, a judge can only be removed for physical or mental inability to

38. See Elizabeth Wanjama Muli, Consultant's Report to the legal Sector Reform Coordinating COMmiтtee 12 (1999) (reporting that the judiciary is taking steps to implement aspects of the Kwach Report recommendations). See also Tops Manacement Consultants, The Kenyan Judiciary Service: Delivery Survey (1999).

39. GATHII, supra note 8 , at 11 .

40. See Days Et Al., supra note 19, at 18 .

41. United Nations Basic Principles on the Independence of the Judiciary, princ. 12, 7th U.N. Congress on the Prevention of Crime and the Treatment of Offenders, U.N. Doc. AVCONF.121/22/Rev.1 (1985) at 59. The document further provides that:

Decisions in disciplinary, suspension or removal proceedings should be subject to an independent review. This principle may not apply to the decisions of the highest court and those of the legislature in impeachment or similar proceedings.

Id. at princ. 20.

42. See DAYS Et AL., supra note 19 , at 5 . 
execute the functions of the office or for misbehavior..$^{43}$ It is the President, however, who has the power to remove a judge upon the recommendation of a five-member tribunal that he appoints. ${ }^{44}$ The mechanism for removal begins when the Chief Justice suggests to the President that such a course ought to be pursued. The President then appoints a tribunal to consider the matter and make recommendations. The President may also appoint a panel to consider the removal of the Chief Justice. As correctly pointed out by a group of American lawyers, these removal procedures leave a lot to be desired.

The current security-of-tenure protections also pose problems. The Executive can easily circumvent the procedures for independent judicial removal proceedings. Judges may be removed only by the recommendation of a fivemember tribunal, but the President chooses those members. Thus the President has great discretion in determining the make-up of this tribunal. This degree of Presidential discretion and the composition of the independent tribunal raises questions about the protections provided for the security of judicial tenure. ${ }^{45}$

However, the Constitution is not clear on the legal character of the recommendations made by the tribunal to the President. It seems that such recommendations are not legally binding on the President. Such tenuous tenure protections are heightened in Kenya where judges, once they are removed from the bench, are prohibited from practicing law before its courts. This increases the pressure on judges to do the state's bidding because employment as practicing lawyers is forbidden upon removal or retirement from the judiciary.

Magistrates, of course, face an even harsher fate. Their professional lives are governed by the JSC regulations and the Magistrates Courts Act, which are neither guided by, nor based on, the principle of judicial independence. ${ }^{46}$ Magistrates, who are treated by the JSC as civil service employees in need of strict supervision and as lacking in the capacity for independence, have never been permitted to entertain the notion of tenure. The ISC has the power to "hire, discipline, promote and dismiss magistrates on various grounds specified in the regulations." ${ }^{47}$ Unlike judges, magistrates do not even get a presidentially-dominated removal process.

43. See Const. of KenYa amend. act no. 1 (1990).

44. The Constitution of Kenya reads:

A judge of the High Court shall be removed from office by the President if the question of his removal has been referred to a tribunal appointed under subsection (5) and the tribunal has recommended to the President that the judge ought to be removed from office for inability as aforesaid or for misbehavior.

Const. OF KenYa ch. IV, pt. I, § 62(4).

45. DAYS ET AL., supra note 19, at 21.

46. See Magistrates Courts Act, CAP. 10, Laws of Kenya.

47. Gatril, supra note 8 , at 11 . 
In Kenya, magistrates courts have been at the forefront of the suppression of basic freedoms and human rights since most political offenses are prosecuted before them. These offenses were created by Draconian colonialera laws that the Moi government still employs to stifle dissent and resist democratic reforms. Among the most notorious are the Chief's Authority Act, which restricts the rights of assembly, movement, and speech. ${ }^{48}$ Others include the Public Order Act, ${ }^{49}$ which gives local officials the right to deny the right to assembly; the Penal Code, ${ }^{50}$ which creates the offense of sedition; and the PPSA, under which one can be detained without trial. ${ }^{51}$ In fact, lower courts, which are burdened by heavy caseloads and poor infrastructure, are under tremendous pressure to keep citizens "in line" or risk the wrath of both the district, provincial, and central executive authorities. Quite often, the most compliant magistrates are raised to the High Court.

Financial and political corruption are so rampant within the society in general, and the magistrates court in particular, that the Kwach Report declared in its "Judicial Rectitude" section that "corruption has taken centre stage." 52 Among other matters, the committee recommended frequent transfers of magistrates, better pay and working conditions, the hearing of all matters in open court, and the introduction of a code of ethics as remedial measures. ${ }^{53}$ Surprisingly, the committee did not address the root causes of corruption within the judiciary. A serious examination of the problem would have unpacked the reality of corruption that the executive practices as official policy, and of which the magistracy partakes as standard routine. It is futile to expect a captive magistracy that acts as an instructed agency of the executive not to engage in moral, professional, and financial corruption. Transfers and better working conditions cannot cure such a cancer. Only an overhaul of the legal and substantive relationships between the judiciary and the executive can start to restore sanity to the system.

\section{SECURITY OF TENURE AND CONTRACT JUDGES}

Early in the life of the republic, President Kenyatta devised the notion of hiring non-Kenyans on contract to serve on the High Court and Court of

48. See Chief's Authority Act, CAP. 128, Laws of Kenya.

49. See Public Order Act, CAP. 56, Laws of Kenya.

50. See Penal Code, $\S 56$ \& 57, CAP. 63, Laws of Kenya.

51. See Maina Kial, Independence Without Freedom: The Legitimization of Repressive Laws and Practices in Kenra 3 (1994) [a Kenya Human Rights Commission Publication] for an elaboration of these repressive laws.

52. Republic of Kenya, Report of the Committee on the Administration of Justice 9 (1998).

53. See id. at 11 . 
Appeal. This was a sure way of keeping the judiciary loyal to him. ${ }^{54}$ "Contract judges," predominantly British citizens, were literally hired guns who needed no encouragement to do the government's bidding. It is important to note at the outset that the Constitution makes no provision for contract judges, and as such they are covered by all the provisions and protections that relate to the judiciary in matters of appointment, tenure, and removal. Thus, they cannot be constitutionally removed by adhering to the relevant constitutional provisions. However, the KANU government, in clear violation of the Constitution, has treated contract, expatriate judges as a special species hired by it to carry out its express or perceived wishes or face disciplinary action, including summary removal, without regard to the Constitution. Kiai described their circumstances well. "Their contracts were renewable at the government's option, and since most of these judges could never attain such positions and comfort in their home countries, they were jittery about attracting the wrath of the government. ${ }^{155}$

There is widespread agreement among observers of the judiciary that the institution of the contract judge, which is often financially supported by the British Overseas Development Administration (ODA) at the request of the Kenyan government, is corrosive and undermines judicial independence. Supporters even resorted to the racist argument that expatriate judges were incorruptible because they did not have any African ethnic loyalties. An African government was ready to impugn the dignity of its own citizens by suggesting that Africans are more corruptible than whites in order to justify hiring judges it would control. ${ }^{56} \mathrm{~A}$ former contract judge explained the economics of the institution in the following language:

[T]hey [contract judges] are there because they have a nice job, which they cannot get in England. This is not the old-style colonial legal service where you had career judges going from one place to another-these are not judges of considerable experience coming from another territory. They are-with exceptions-judges who are hanging on to the job and therefore susceptible to local pressures. ${ }^{57}$

Some contract judges have gone too far in proving their loyalty to the government. One, former Chief Justice Alan Robin Hancox, went so far as to urge all lawyers and judges "to be Loyal to Government and to the Head of

54. See KiAl, supra note 51, at 18. (During President Kenyatta's fifteen-year reign, only one native black African Kenyan, Kitili Mwendwa, served as Chief Justice, and only for a scant two-year period from 1969-1971. In 1978, upon President Kenyatta's death, twelve out of nineteen judges on the High Court and Court of Appeal were foreigners on contract.)

55. Id.

56. See DaYs Et Al., supra note 19 , at $23-25$.

57. See Lucy Hannan, Bias and Judicial Outrage, 141 New L.J. 900 (28 June 1991), available on LEXIS, Secondary Legal: Legal News File. 
State." ${ }^{58}$ In general, contract expatriate judges have ruled in favor of the government and KANU in matters where their actions were challenged as undemocratic, unconstitutional, or illegal. Contract judges who have exhibited any measure of independence have either been summarily terminated or punished by the Chief Justice through some administrative device, such as a transfer to a remote location or removal from hearing particular matters.

The history of executive interference with judicial independence, and in particular the security of tenure, has deep roots in Kenyan history. Cases abound to prove these insidious intrusions into the judicial sphere. For instance, in 1969 following the banning of the opposition KPU and the arrest and detention of its key leaders, Justice G. Farrel and Acting Chief Justice Dalton reduced the sentence of Bildad Kaggia, the KPU vice president from twelve to six months. ${ }^{59}$ In what looked like a strange coincidence, President Kenyatta appointed Kitili Mwendwa Chief Justice on the day of the ruling, and a few days later Justice Farrel "retired" from the bench. ${ }^{60}$ Barely two years later, Mwendwa himself was forced to resign after a failed coup attempt. ${ }^{61}$ President Kenyatta was reportedly unhappy with Mwendwa's business interests. ${ }^{62}$ In September 1985, Mwendwa was killed in a suspicious automobile accident. ${ }^{63}$

A stunning example of executive interference with the judiciary involved the fate of Justice Derek Schofield, an expatriate contract judge. In 1987, Justice Schofield was hearing a habeas corpus application for Mbaraka Karanja who had been shot dead and buried by the police without notification to his family. Justice Schofield then held the Director of Criminal Investigation in contempt for his failure to locate and exhume Karanja's body. According to Justice Schofield, Chief Justice Miller summoned him and told him to disqualify himself from the case on the orders of President Moi. ${ }^{64}$ Justice Schofield asked Chief Justice Miller to tell President Moi that it was improper to interfere with the judiciary. ${ }^{65}$ Chief justice Miller then removed the case from Justice Schofield, and later revealed that he had

58. See M.M. Kioga, Chief Justice's Pronouncements: (Are they Law or Politics?), 23 NaIROBI L. Mon. 7 (Apr./May 1990).

59. See Kaggia v. Republic, E. Afr. L. Rep. 451 (1969).

60. See GathiI, supra note 8 , at 10.

61. See id. at 10; see also, Colin Leys, Underdevelopment in Kenya: The Political Economy of NeoColonialism (1975).

62. See When it Comes to Judges, Most of them Have Gone Quietly, Wefkry Rev., 5 Aug. 1988 , at 9.

63. See Death in a Car Crash of Kenya's First African Chief Justice, BBC SUMmarY of WORID BRoAdCASTS, 1 Oct. 1985, available on LEXIS, News Library, ARCNWS File.

64. See Why I left Kenya-Schofield, 41 NaIrobI L. Mon. 49 (Feb./Mar. 1992) [Speech to the Cayman Bar Association]; see also Dars et AL., supra note 19, at 23.

65. See id. 
taken the action after the receipt of "secret documents" from the Office of the Attorney General.66 Rather than comply with these illegal actions, Justice Schofield resigned and left the country. He later summed up the state of the Kenyan judiciary thus: "the Chief Justice and some of the judges saw it as their duty to assist the President [Moi] and the government [KANU government] ... Thus the superior courts tended to support the government and particularly the President [Moi] grew to expect compliance with his wishes." 67

In 1988, the following year, Chief Justice Miller dismissed Justice Patrick $\mathrm{O}^{\prime}$ Connor in clear violation of the Constitution. Upon receipt of a termination letter from the Chief Justice for refusal to accept a transfer from Nairobi to Meru, a rural agricultural district, Justice O'Connor questioned the constitutional authority of the Chief Justice to fire him. ${ }^{68}$ The Constitution provides for a tribunal to consider the matter and make recommendations on removal to the President. Reemphasizing the extraordinary degree of executive control over the judiciary, the Head of the Civil Service and the Permanent Secretary in the Office of the President, Joseph Letting, stated:

I wish to inform the public and all interested parties that in relieving Mr. Justice $\mathrm{O}^{\prime}$ Connor of his duties, the Chief Justice, who is Chairman of the Judicial Service Commission, acted within the powers vested in him by the Constitution of this country. ... Under the Constitution of Kenya, the power to exercise disciplinary control over judges or to remove them from office are vested with the Judicial Service Commission ... which can delegate its powers to any of its members including the Chief Justice. ${ }^{69}$

It was soon after O'Connor's removal that President Moi rammed through Parliament-in a bare three hours - the infamous 1988 constitutional amendment deleting the judicial tenure provisions of the independence Constitution. ${ }^{70}$ Even the usually pro-government Weekly Review decried the measure and chastised legislators for being "resigned" and "more jovial than serious" in passing the bill desired by the executive, although it "touched on some of the most fundamental tenets of the country's constitution, involving the independence of the judiciary from political control."

66. See Gitobu Imanyara, The Office of the Chief Justice and Chief Justice Hancox's Challenge, Nairobi L. Mon., Sept./Oct. 1989, at 18; see also Dars Er At., supra note 19, at 75 , note 43.

67. Schofield, supra note 64 , at 50 .

68. See Gathil, supra note $\mathbf{8}$, at 13.

69. Id.

70. See Parliament Amends the Constitution with Surprising Alacrity, Wefkly Rev., 5 Aug. 1988 , at 3.

71. Id. 
The formal restoration of the constitutional provisions guaranteeing the security of tenure of judges has not in fact protected judicial tenure in Kenya. In 1994, the government revoked the contract of Justice Edward Torgbor, a Ghanaian contract judge. ${ }^{72}$ The previous year, the government declined to renew the expired contract of Justice J.A. Couldrey. ${ }^{73}$ Justices Torgbor and Couldrey were both terminated after ruling that an election petition against President Moi by an opposition party leader was validly filed ${ }^{74}$ Again, it is instructive that the Head of the Civil Service and the Secretary to the Cabinet wrote to Justice Torgbor ahead of the expiry of his contract advising him that the government would not be renewing it. ${ }^{75}$ Needless to say, the constitutional safeguards for the removal of judges were blatantly abrogated in cases of Justices Torgbor and Couldrey.

Virtually no manifestation of independence by judges has gone unpunished. For instance, in 1992, Justice Thomas Mbaluto ruled against the KANU dominated Electoral Commission for reducing the period required for nomination of candidates and the conduct of campaigns in advance of the 1992 general elections. ${ }^{76}$ Amos Wako, the Attorney General, had used a formal procedure to amend the National Assembly and Presidential Elections $\mathrm{Act}^{77}$ in order to shorten the time for nomination of candidates, knowing fully well that only the opposition political parties would be disadvantaged by the change. Justice Mbaluto disallowed the amendment and ruled that the Attorney General's action could "only be construed to have been a misuse if not an abuse of the powers conferred upon his office." ${ }^{18} \mathrm{He}$ added that in his "view that was clearly illegal."79 As he delivered his ruling, Justice Mbaluto was twice interrupted by telephone calls from Phillip Mbithi, the Head of the Civil Service and Secretary to the Cabinet, ostensibly seeking to alter the judgment. ${ }^{80}$ Soon thereafter, Justice Mbaluto was transferred from Nairobi to Mombasa, and then to Kisii, a rural

72. See Gitau Warigi, Kenya's Memory of Expatriate Chief Justices, Africa News, 10 Dec. 1997, available on LEXIS, News Library, ARCNWS File.

73. See id.

74. See Kenneth Stanley Njindo Matiba v. Daniel Toroitich arap Moi and Others, Election Petition No. 27 of 1993 (1 july 1993).

75. See Charles Wachira, Kenya Politics: A Judiciary Under Siege, Inter Press Serv., 16 July 1994, available on LEXIS, News Library, ARCNWS File. See also Dally NATION, 2 June 1994, at 32; STANDARD, 2 June 1994, at 5.

76. See Jaramogi Oginga Odinga, Gitobu Imanyara and Hassan Kadir v. The Electoral Commission, reported in NAIROB: L. MON. Oct./Nov. 1992, at 46 [hereinafter Imanyara \& Hassan].

77. See National Assembly and Presidential Elections Act, CAP. 7, Laws of Kenya.

78. Imanyara \& Hassan, supra note 76 , at 44.

79. Id. at 44 .

80. See Robert F. Kennedy Memoriat Center for Human Rights, Kenya at the Crossroads: Demands for Constitutional Reforms Intensify 9 (1997) [hereinafter Kenya at the Crossronds]. 
farming district in the west of the country. ${ }^{81}$ Justice Frank Shields, another contract judge who consistently exhibited independence from executive wishes, also failed to have his contract renewed in $1994 .{ }^{82}$

Disrespect for the rule of law by the executive extends to other fora beyond the formal judiciary, such as the Judicial Commission of Inquiry investigating the murder in 1990 of Dr. Robert Ouko, then Minister for Foreign Affairs and International Cooperation. ${ }^{83}$ Independent investigators from the Scotland Yard testified before the Commission that Nicholas Biwott, cabinet minister and the closest ally of President Moi, had, together with Hezekiah Oyugi, chief of internal security, masterminded Ouko's murder because he knew of and was opposed to their notorious corruption. ${ }^{84}$ As corruption and other incriminating evidence against Biwott, then the second most powerful person in Kenya, and other senior ministers quickly accumulated, the finger started to point at President Moi. On 26 November 1991, President Moi abruptly disbanded the Commission before it could conclude the proceedings. ${ }^{85}$ As noted by Gathii, on the same day "the three judges [on the Commission] publicly complained about the threats, intimidation and tapping of their hotel rooms by the police." ${ }^{186}$

There is no indication that the Kenyan judiciary will recapture its independence any time soon. President Moi's 1997 appointment of Chesoni to the post of Chief Justice signaled that the executive was determined to keep the bench compliant. ${ }^{87} \mathrm{~A}$ pro-government judge, Zachaeus Chesoni was the former chair of the Electoral Commission, the body that oversaw the 1997 presidential and parliamentary elections. Mired in personal legal problems, Chesoni was widely viewed as having made the Electoral Commission a docile instrument for KANU and the government. ${ }^{88}$ The Law Society of Kenya and its chair, Nzamba Kitonga, opposed his elevation, fearing that he would not be independent. ${ }^{89}$

Bernard Chunga, who succeeded Chesoni in 1999, is also very close to KANU and President Moi. He became only the third native black African Kenyan chief justice since.independence. In 1998, President Moi appointed him lead counsel to the Commission on Ethnic Clashes, which investigated

\footnotetext{
81. See Gathil, supra note 8 , at 17 .

82. See id. at 19.

83. See Makau Mutua, A Break with the Past, Afr. Rep., Jan./Feb. 1992, at 21.

84. See id. at 22.

85. See id.

86. Gathli, supra note 8 , at 22 .

87. As the newly appointed Chief Justice, Chesoni was only the second native black African Kenyan to head the judiciary.

88. See Kenya's New Cl Has Rough Start to Term of Office, Afr. News, 10 Dec. 1997, available on LEXIS, News Library, ARCNWS File.

89. See id.
} 
"ethnic violence." ${ }^{100}$ Since 1991, thousands of Kenyans have been killed and more than 300,000 displaced in government sponsored political violence targeted at members of communities perceived to be supporters of opposition political parties. ${ }^{91}$ When Chunga took over as lead counsel, he denied access to witnesses who wanted to testify about the active involvement of government officials in instigating, fostering, and allowing the violence. ${ }^{92}$ While Chief Justice Chunga has admitted that corruption is a major problem, he has not addressed the critical issue of judicial independence from the executive. ${ }^{93}$ No one expects him to depart from the practices of his predecessors.

\section{THE JUDICIARY: AN AGENCY OF THE EXECUTIVE}

The Kenyan courts have often evaded their constitutionally mandated responsibility to protect individual rights. The courts have stood aside as the Kenyan government has used the Preservation of the Public Security Act (the Kenyan detention law) as an instrument of political repression. The courts have largely refused to review allegations of torture or other mistreatment. "In the face of judicial inaction, blatant political prosecutions for treason and sedition have proceeded without serious examination of the constitutional values at risk." ${ }^{\prime 94}$

Those were the conclusions of a human rights report in $1992 . .^{95}$ In the eight years since, not much has changed. The courts continue-as they have throughout Kenya's history - to act as an agency of KANU, the ruling party and the state. Frankly, it is not just the executive that is to blame for the dependence of the judiciary. Judges themselves have bent over backwards to accommodate the wishes of the executive for financial and political rewards. Few in the judiciary have resisted executive intrusions and many seem to think like civil servants and ruling party stalwarts. Patronage and cronyism are so endemic that most of those appointed to the judiciary and the magistracy are either mediocre or flatly incompetent.

90. Human RightS Watch, supra note 6, at 49.

91. See id. See also Joel A. Solomon, Falling the Democratic Challence: Freedom of Expression in Multipartr Kenya-1993 15-21 (1994) [a publication of the Robert F. Kennedy Memorial Center for Human Rightsl; Int'l Human Rights Law Group, Facing the Pluralist Challenge: Human Richts and Democratization in Kenya's December 1992 Multi-Party Elections 14 (1992); Africa Watch, Divide and Rule: State-Sponsored Ethnic Violence in Kenya (1993).

92. See id.

93. See Chief Justice Gives Pledge Over Graft, Afr. News, 5 Mar. 2000, available on LEXIS, News Library, CURNWS File.

94. DAYS ET AL., supra note 19, at 9.

95. See id. at 9 . 
There have been many particularly shocking instances of judicial timidity and complicity with the executive over the last decade. In 1988, for example, Justice Akiwumi refused to entertain the claim of a KANU member who alleged that the party's nomination process had denied him certain constitutional rights. ${ }^{96}$ Surprisingly, Justice Akiwumi decided that the High Court lacked jurisdiction to look into the constitutionality of KANU's actions with regard to the electoral rights of aspirants, even though the High Court has unlimited original jurisdiction on all matters, civil and criminal. In effect, the High Court held that KANU was free to determine for itselfwithout judicial review-the limitations that it could place on the political process.

Another important instance involved government and judicial collusion to stop the LSK from leading the crusade for the restoration of multipartyism, thus ending KANU's political monopoly as the only sole legal political party. After Paul Muite was elected chair of the LSK, he called on the government to legalize the political opposition. Following the speech, four members of the LSK, reportedly acting at the behest of the Attorney General, successfully asked the High Court to restrain Muite and other LSK Council members from "making any political statements, conducting business of the LSK in any manner political, making any statements which might cause political disaffection, or permitting Mr. Muite to preside over or participate in any LSK Council meetings." 97

Justice Norbury Dugdale, a contract judge, granted the application against Muite and the members of the LSK Council. Justice J.A. Mango later upheld the ruling and noted that calls by the LSK for the government to allow the registration of opposition political parties other than KANU "amounts to inciting the public to defy the law and creates contempt for the lawmakers." 98 The High Court further noted that "it is definitely not within their [LSK Council] scope to advise the public their version is the right one as opposed to that of the government" and that such statements amounted "to confusing the public." 99 The cowardice of the High Court in responding to a despotic executive was chilling. It said that failure to restrain the defendants from their "confrontational attitude against the government"

96. See James Kefa Wagara and Rumba Kinuthia v. John Anguka and Ngaruro Gitahi, High Court of Kenya, Civil Case No. 724 of 1988. See Githu Muigai, The Judiciary and the Search for a Philosophy of the Law: the Case of Constitutional Adjudication, in LAW AND the Administration of Justice in Kenra 110-12 (Kivutha Kibwana ed., 1992) la publication of the International Commission of Jurists-Kenya Section].

97. See Days et Al., supra note 19, at 52 .

98. Aaron Gitonga Ringera \& 3 Others v. Paul K. Muite \& 10 Others, Civil Suit No. 1330 of 1991 (30 Apr. 1991).

99. Id. at 12. 
would lead it to flex its muscles and ban the LSK. ${ }^{100}$ It added, "God forbid, but it is a real and live possibility, given the circumstances." 101 An application by the LSK to the Court of Appeal seeking a stay of execution was rejected. ${ }^{102}$ In November 1991, the order was mooted when the government was forced to lift the prohibition on political parties.

Executive interference and its dictation to the judiciary and the magistracy are commonplace. It has been known for a long time that the Chief Justice, for example, issues "circulars" to judges instructing them on how to rule in particularly sensitive matters. ${ }^{103}$ In 1993, when President Moi directed magistrates not to grant bail to suspects charged with the illegal possession of firearms, the Chief Justice issued a circular instructing magistrates to comply. ${ }^{104}$ To underscore the point, the police stormed into a court in Molo and "without warning, notice or courtesy to the magistrate" took an accused from the dock because they thought the magistrate was in violation of the circular. ${ }^{105}$ The suspect was later tried before Nakuru Chief Magistrate William Tuiyot, a KANU loyalist. ${ }^{106}$

The government has reacted offensively in the rare occasions when judges and magistrates have expressed their desire for independence from the executive. In 1996, for example, magistrates at a judicial seminar in Embu complained about executive interference and called for reforms to protect them from retaliatory attacks by the presidency. ${ }^{107}$ Similar sentiments were expressed at a meeting of the Kenya Magistrates and Judges Association in March 1997. ${ }^{108}$ To stem these assertions of independence, the Attorney General and the Chief Justice have stopped judges and magistrates from attending meetings with colleagues in other countries. In January 1996, the Chief Justice barred judges from attending an East African judicial conference in Arusha, Tanzania. ${ }^{109}$ Shockingly, the Attorney General and the Chief Justice stopped judges from attending the annual meeting of the East African Law Society held in April 1997 in Mbarara, Uganda. ${ }^{110}$ Even the cautious and pro-establishment International Bar Association lamented the state of the Kenyan judiciary in this remarkable statement:

100. Id. at 17 .

101. Id

102. See Gathll, supra note 8 , at 21 .

103. See Kenya at the Crossroads, supra note 80 , at 9.

104. See id. at 10. See also Democratisation, supra note 5, at 58-59 for the full text of another circular issued by the Chief Justice in 1996, instructing magistrates to deny bail to particular offenders, the law and the Constitution notwithstanding. It asked the Attorney General to instruct public prosecutors accordingly.

105. See Kenya at the Crossroads, supra note 80, at 10.

106. See id.

107. See E. Afr., 3 June 1996.

108. See Judges Condemn State Interference, Sunday Nation, 9 Mar. 1997.

109. See Kenra at the Crossroads, supra note 80, at 11.

110. See Dally Nation, 5 Apr. 1997. 
In a country where a Chief Justice directs the judiciary to comply with statements made in a political speech by the President, one can hardly expect lay people to accept that judges and magistrates ignore the wishes of the President as to the outcome of cases serving before them. In short, whatever judicial independence there may be in Kenya, there certainly, with few exceptions, does not seem to be a proper degree of independence of the judiciary from the main executive arm."11

\section{THE COURTS AND THE GOLDENBERG SCANDAL}

The corruption case known popularly as the Goldenberg Scandal has shown the complete inability of Kenyan courts to effectively and fairly adjudicate or try any matter in which senior officials of the government are in jeopardy. The Goldenberg Scandal, the longest running case of massive high level corruption in Kenyan history, was exposed in 1993."12 It involved a fraudulent scheme in which the government was defrauded of hundreds of millions, if not billions, of dollars in public funds. Seven years later, those culpable have not been punished. ${ }^{113}$

The facts of the scandal are stunning. Kamleshi Pattni, a businessman, reportedly devised a scheme in which his company, Goldenberg International Ltd., purported to have exported gold and diamonds worth hundreds of millions of dollars." ${ }^{14}$ Kenya is not a large exporter of either gold or diamonds. Pattni then presented fictitious, fabricated export compensation claims for payment by the Central Bank of Kenya. ${ }^{15}$ World Duty Free Ltd. was indicated in Pattni's documentation as the consignee of the exports. ${ }^{116}$ Nasir Ali, the owner of World Duty Free Ltd., has categorically denied these allegations and offered his own testimony in which he linked President Moi to the scandal. ${ }^{117}$ According to most observers, credible evidence suggests that President Moi and his senior aides were involved in the sordid affair. ${ }^{118}$ The International Monetary Fund (IMF) was so upset by the level of official graft and the Goldenberg Scandal that it suspended funding to Kenya in

111. See Kenya at the Crossroads, supra note 80 , at 10.

112. See Catherine Gacheru, Goldenberg: It Goes to the Top, Dally Nation, 5 Oct. 2000, available on LEXIS, News Library, CURNWS File.

113. See id.

114. See Six Days Later, Kenya Deports Ali, Africa News, 3 Aug, 1999, available on LEXIS, News Library, CURNWS File.

115. See id.

116. See id.

117. See M. Warsama, Justice System Put to the Test as MPs Sue Ali Lawyer, Africa News, 17 Aug. 1999, available on LEXIS, News Library, CURNWS File.

118. See, e.g., Joel D. Barkan, Leakey Saved Elephants: Now the Public Purse?, Christian Sci. News Monitor, 11 Aug. 1999, at 9. 
1997. ${ }^{119}$ The Kenyan government placed Ali's duty-free shops on receivership and deported him from the country. ${ }^{120}$ Domestic remedies, if they exist, are unavailable in this case because the state has manipulated the legal system and employed both extra-judicial and political measures to block any resolution.

The government of Kenya has thwarted every attempt to investigate and prosecute those suspected of involvement in the Goldenberg Scandal. Although acting under constitutionally granted authority, the Attorney General's use of the power of nolle prosequi to stop prosecutions in the Goldenberg matter looks like a protection racket for high-ranking officials. ${ }^{21}$ Clearly, the power to discontinue a prosecution should not be used to conceal or prevent the punishment of a crime by a public official or to thwart the rule of law. But the Attorney General appears to have invoked this power when he discontinued two suits on the Goldenberg matter for precisely these reasons. In the first, Raila Odinga, an opposition politician, had filed suit against Vice President George Saitoti and six other senior officials for conspiracy to defraud the government in the scandal. In the other, the Attorney General stopped an effort by the LSK to privately prosecute senior government officials implicated in the scandal. ${ }^{122}$ It was only after a parliamentary committee investigation and the insistence of the foreign donors that the Attorney General initiated a half-hearted prosecution, apparently to blunt domestic and international pressures. ${ }^{123}$

The deportation of Ali and the obstruction by the KANU government spell doom for any meaningful resolution to the scandal. In any case, it underscores the inability of the Kenyan legal system-and its judiciary in particular-to uphold the rule of law, particularly in this case of historic corruption by high governments officials. The use of the Office of Attorney General, the police, and security apparatus to cripple the judiciary portends a bleak future for the state and the country.

119. See Human Rights Watch, supra note 6, at 50; Razia Khan, Kenya's Reform May Appease International Monetary Fund, BRIDGe News, 10 Feb. 2000, available in LEXIS, News Library, CURNWS File.

120. See Six Days Later, supra note 114.

121. See Const. of Kenya ch. II, pt. III, $\S 26(3)(c)$. (The Constitution of Kenya permits the Attorney General to "discontinue at any stage before judgement is delivered any such criminal proceedings instituted or undertaken by himself or another person or authority.")

122. See Kenya at the Crossroads, supra note 80 , at 6 .

123. See id. 


\section{CONCLUSION}

The purpose of this study was to demonstrate the subservience of the Kenyan legal system, and in particular its judiciary, to President Moi, the ruling party KANU, and the executive in general. Since independence in 1963, the presidency has abrogated, through both legal and illegal means, the constitutional coequality and separation of powers of the three branches of the state. Not even the facade of judicial independence has been maintained. President Kenyatta, and more blatantly his successor, President Moi, made the judiciary into an instructed agency of the Office of the President. Successive chief justices have served as the personal envoys of President Moi in making sure that executive wishes were executed by both the superior and subordinate courts without deviation. In the rare instances where individual judges or magistrates have demonstrated even the slightest evidence of independence, the executive has acted swiftly. Such errant judicial officers have either been terminated, punished administratively or professionally ruined. President Moi has permitted no margin for individuality within the judiciary.

Today, Kenya is technically a multi-party state, in which opposition parties occupy a significant portion of the legislative pie. Yet President Moi and the KANU government have refused to permit democratic reform of the country. ${ }^{124}$ Steeped in the culture of the one-party state, President Moi has transformed virtually all state apparatuses from the legislature to the judiciary and the police and security services into instruments of personal rule. Aided by draconian colonial-era laws, President Moi has stifled and violently suppressed most civil, political and expressive rights, including those of speech, assembly, and due process. ${ }^{125}$ Opposition political figures, independent businessmen, the press, and principled members of the bar, among others, risk financial and professional ruin-if not worse-for their perceived opposition to President Moi and the KANU brass. Regrettably, the corrupt Kenyan judiciary, the one possible venue for protecting human rights and punishing their violation, has willingly become a compliant instrument of repression.

124. See Willy Mutunga, Constitution-Making from the Midole: Civil Society and Transition Politics IN KENYA 1992-1997 (1999) (describing a comprehensive and in-depth analysis of the contest for democratic reforms by civil society organizations and the intransigence of the Kenya government).

125. See Alamin Mazrui, Kayas of Deprivation, Kayas of Blood: Violence, Ethnicity, and the State in Coastal Kenya (1997) [a Kenya Human Rights Commission publication]; Mutuma Ruteere, Dying to be free: The Strugcle for Rights in Mwea (2000) [a Kenya Human Rights Commission publication]; Mutuma Ruteere, Mission to Repress: Torture, Illegal Detention, and Extrajudicial Killings by the Kenyan Police (1998) [a Kenya Human Rights Commission publication]; Amnesty International, Torture: Compounded by the Denial of Medical Care (1995) (depicting catalogues of gross human rights violations by the Kenya government). 